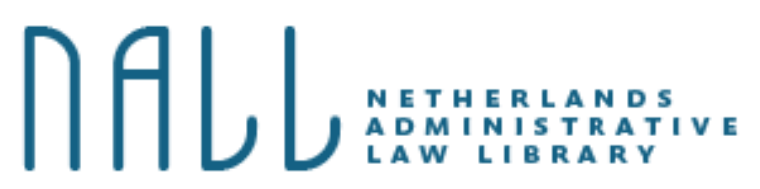

Citeerwijze van dit artikel:

$\mathrm{mr}$. Inge mrs van der Veen, 'Aandacht voor de proceskostenvergoeding in bezwaar', NALL 2013, april-juni, DOI: 10.5553/NALL/.000010

DOI: 10.5553/NALL/.000010

\title{
Aandacht voor de proceskostenvergoeding in bezwaar
}

mr. Inge mrs van der Veen

\section{Inleiding}

Bestuursorganen nemen talrijke besluiten. Het is onvermijdelijk dat daarbij fouten worden gemaakt. De bezwaarschriftenprocedure is onder meer bedoeld om hen de mogelijkheid te bieden deze fouten te herstellen. ${ }^{\mathbf{1}}$ Hoe het zit met de daaraan verbonden kosten is geregeld in artikel 7:15 van de Awb. Het eerste lid bepaalt dat voor de behandeling van het bezwaar geen recht is verschuldigd. Het tweede lid gaat over vergoeding van de in bezwaar gemaakte proceskosten. ${ }^{2}$ Daarin is bepaald dat de proceskosten, die de belanghebbende in verband met de behandeling van het bezwaar redelijkerwijs heeft moeten maken door het bestuursorgaan uitsluitend worden vergoed op verzoek van de belanghebbende voor zover het bestreden besluit wordt herroepenwegensaan het bestuursorgaan te wijten onrechtmatigheid. Volgens het derde lid is voorts vereist dat de burger dat verzoek doet voordat het bestuursorgaan op het bezwaar heeft beslist en beslist het bestuursorgaan op het verzoek bij de beslissing op bezwaar. 3

Het tweede en derde lid van artikel 7:15 van de Awb zijn, tezamen met vierde lid over kosten die voor vergoeding in aanmerking komen en de vaststelling van die vergoeding, met de inwerkingtreding van de Wet kosten bestuurlijke voorprocedures ${ }^{\mathbf{4}}$ per 12 maart 2002 in de Awb terecht gekomen. ${ }^{\mathbf{5}}$ De wetgever heeft met deze wet bewust voor de in bezwaar gemaakte proceskosten een terughoudendere vergoedingplicht in het leven willen roepen dan voor die in beroep. De ruime jurisprudentie die inmiddels onder deze wet is ontstaan, maakt het interessant om aan bepaalde aspecten van de proceskostenvergoeding in bezwaar nadere aandacht te schenken tegen de achtergrond van de proceskostenvergoeding in beroep.

In deze bijdrage laat ik zien dat de uitleg die in de jurisprudentie wordt gegeven aan het vereiste voor vergoeding van de in bezwaar gemaakte proceskosten dat het besluit wordt herroepen wegens aan het bestuursorgaan te wijten 
onrechtmatigheid niet helemaal overeen lijkt te komen met hetgeen de wetgever daarmee voor ogen stond. Voorts laat ik zien dat bij bestuursorganen en rechters regelmatig misverstanden bestaan over het procesbelang als de burger alleen nog belang heeft bij de inwilliging van zijn verzoek om vergoeding van zijn in bezwaar gemaakte proceskosten, omdat het oorspronkelijke geschil met de herroeping van het bestreden besluit is opgelost, of bij de herroeping geen belang meer bestaat. Zoals zal blijken speelt daarbij een rol dat de regeling van de in bezwaar gemaakte proceskosten afwijkt van die in beroep en zeer waarschijnlijk ook dat het niet direct voor de hand ligt, dat bij geschillen over nog uitsluitend de in bezwaar gemaakte proceskosten het bezwaar, dan wel het (hoger) beroep inhoudelijk moet worden beoordeeld.

Dit roept de vraag op of de vergoeding van de in bezwaar gemaakte proceskosten toch niet beter op dezelfde manier kan worden geregeld als de vergoeding van de in beroep gemaakte proceskosten. In deze bijdrage ga ik daar op in.

Eerst komt aan bod de achtergrond van de Wet kosten bestuurlijke voorprocedures (paragraaf 2). In de paragraaf daarna komt aan de orde de in de jurisprudentie gegeven uitleg aan het vereiste van herroeping van het bestreden besluit wegensaan het bestuursorgaan te wijten onrechtmatigheid voor vergoeding van de in bezwaar gemaakte proceskosten. Ter vergelijking komt daarin ook aan de orde wanneer aanspraak kan worden gemaakt op vergoeding van de in beroep gemaakte proceskosten (paragraaf 3). De volgende paragraaf gaat over het procesbelang als het geschil nog uitsluitend gaat over de in bezwaar gemaakte proceskosten en, ter vergelijking, ook die in (hoger) beroep, omdat het bestreden primaire besluit is herroepen, of de burger daarbij niet langer belang heeft (paragraaf 4). Daarna volgt na een korte terugblik en een blik vooruit, als de in bezwaar gemaakte proceskosten inderdaad op dezelfde manier zouden worden vergoed als die in beroep, mijn antwoord op de opgeworpen vraag (paragraaf 5).

\section{De geschiedenis van de totstandkoming van de Wet kosten bestuurlijke voorprocedures}

Voordat ik aandacht besteed aan de in de jurisprudentie gegeven uitleg over het vereiste dat het bestreden besluit wordtherroepen wegensaan het bestuursorgaan te wijten onrechtmatigheid in artikel 7:15, tweede lid, van de Awb ga ik hier eerst in op hetgeen de wetgever met de Wet kosten bestuurlijke voorprocedures voor ogen stond.

Bij de invoering van de Awb in 1994 werd met artikel 8:75, eerste lid, van de Awb de rechtbank bij uitsluiting bevoegd gemaakt een partij te veroordelen in de proceskosten in beroep en hoger beroep. ${ }^{\mathbf{6}}$ Hiermee werd beoogd in de Awb aan de bestuursrechter de exclusieve bevoegdheid te geven zich over de proceskosten uit te spreken bij een bestuursrechtelijke procedure. Volgens de regering bestond er geen aanleiding in de Awb een soortgelijke bepaling op te nemen voor de proceskosten in de bestuurlijke voorprocedures. Het karakter van die procedures, waarin het primair gaat om de heroverweging van het bestreden primaire besluit, rechtvaardigde volgens haar dat deze proceskosten in de regel 
voor rekening van de burger blijven. Pas als zou blijken dat de administratieve rechter of de burgerlijke rechter in de regel een vergoeding van de proceskosten, gemaakt in een bestuurlijke voorprocedure zou toewijzen, bestond er naar haar mening aanleiding te bezien of deze kosten, om ze te begrenzen, onder bereik van de regeling van de proceskostenvergoeding moesten worden gebracht. ${ }^{7}$

Waar de regering beducht voor was gebeurde. De burgerlijke rechter bleek royaal te zijn in de toekenning van een vergoeding voor de in bezwaar gemaakte proceskosten. Hij sloot aan bij het vereiste van toerekenbaar onrechtmatig handelen in artikel 6:162 Burgerlijk Wetboek. ${ }^{\mathbf{8}}$ Bovendien was de vergoeding ruimer, aangezien hij geen forfaitaire vergoeding toekende krachtens het op artikel 8:75 van de Awb gebaseerde Besluit proceskosten bestuursrecht, maar koos voor een integrale vergoeding van de proceskosten. Ten aanzien van de kosten voor rechtshulp gold daarbij wel dat zowel het inroepen daarvan, als de omvang van de kosten redelijk moesten zijn (de zogenoemde dubbele redelijkheidstoets). Naar aanleiding van deze jurisprudentie van de burgerlijke rechter besloot de regering voor de vergoeding van de proceskosten in de bestuurlijke voorprocedures een regeling in de Awb te treffen.

De Wet kosten bestuurlijke voorprocedures voorziet in de aanvulling van artikel 7:15 van de Awb, waarin is geregeld dat voor de behandeling van het bezwaar geen recht is verschuldigd, met een tweede, derde en vierde lid. Het tweede lid, dat de kosten die de belanghebbende in verband met de behandeling van het bezwaar redelijkerwijs heeft moeten maken door het bestuursorgaan uitsluitend worden vergoed op verzoek van de belanghebbende voorzover het bestreden besluit wordt herroepen wegens aan het bestuursorgaan te wijten onrechtmatigheid, is door een amendement in de wet terecht gekomen. In het oorspronkelijke wetsvoorstel was het vergoedingscriterium minder ruim. Daarin stond namelijk dat het bestuursorgaan de kosten van de bestuurlijke voorprocedure uitsluitend vergoedt, voor zover het bestreden besluit door ernstige onzorgvuldigheid in strijd met het recht is genomen.9

Volgens de memorie van toelichting zou een verdergaande aansprakelijkheid van bestuursorganen voor de kosten van de bestuurlijke voorprocedures tot een ongewenste juridisering van deze procedures leiden, doordat het belang van de rechtmatigheidsvraag zou toenemen. Dat belang zou niet langer beperkte betekenis hebben in de gevallen, waarin het bestuursorgaan geheel of grotendeels aan het bezwaarschrift tegemoet komt. Als voorbeelden werden hier aangehaald de situatie dat na de indiening van een bezwaarschrift alsnog de op grond van Wet openbaarheid van bestuur (hierna: de Wob) geweigerde documenten worden verstrekt en dat alsnog een compromis wordt gesloten in een fiscale zaak. Zodra de rechtmatigheid beslissend wordt voor het al dan niet moeten vergoeden van de kosten van de voorprocedure zou volgens de memorie van toelichting de neiging bestaan de discussie daarover voort te zetten, zelfs als het materiële geschil al is opgelost. Hierdoor zou het conflictoplossend vermogen van de voorprocedure afnemen, terwijl het uit een oogpunt van het tegengaan van onnodige juridisering juist zaak is dit conflictoplossend vermogen te vergroten. Daarnaast werd er op gewezen dat een verdergaande aansprakelijkheid voor de kosten van de bestuurlijke voorprocedure voor bestuursorganen aanzienlijke kosten met zich zou brengen, niet alleen de kosten 
van de vergoedingen zelf, maar ook de kosten van de besluitvorming. ${ }^{\mathbf{1 0}}$

Kamerlid Dittrich heeft zich kritisch uitgelaten over het voorstel om de kosten in de bestuurlijke voorprocedure uitsluitend te vergoeden voor zover het bestreden besluit door ernstige onzorgvuldigheid in strijd met het recht is genomen. Volgens hem kan het niet zo zijn dat als een burger kosten heeft moeten maken in verband met de behandeling van zijn bezwaar en die kosten redelijkerwijs zijn gemaakt de overheid een uitzonderingspositie voor zichzelf claimt, waar anderen in het rechtsverkeer wel de proceskosten voor hun rekening moeten nemen, als is vastgesteld dat zij in strijd met het recht hebben gehandeld.

Hij heeft daarom een amendement ingediend, waarin is voorgesteld voor de vergoeding van de in bezwaar gemaakte proceskosten als criterium te hanteren dat het bestreden besluit in strijd met het recht is genomen, tenzij de onrechtmatigheid van dit besluit aan de belanghebbende is toe te rekenen. ${ }^{\mathbf{1 1}}$

Dit voorstel is niet in de wet terecht gekomen. Er is namelijk nog een wijziging op dit amendement ingediend door Dittrich c.s.. ${ }^{\mathbf{1 2}}$ Met de aanvaarding van dat amendement heeft artikel 7:15, tweede lid, van de Awb zijn huidige tekst gekregen. Volgens de toelichting daarbij komen de kosten aanzienlijk eerder voor vergoeding in aanmerking dan in het regeringsvoorstel. Wel moet de onrechtmatigheid aan de overheid te wijten zijn en leiden loutere vormfouten of motiveringsgebreken niet tot een vergoedingsplicht. Het woord "herroepen" impliceert volgens de indieners van het amendement dat het oorspronkelijke besluit inhoudelijk onjuist moet zijn geweest. Indien de onjuistheid van het besluit te wijten is aan de belanghebbende, bijvoorbeeld omdat hij niet tijdig de juiste gegevens heeft verschaft, bestaat volgens de toelichting geen recht op vergoeding.

De Minister van Justitie merkte over dit amendement op dat de voorgestelde vergoedingsplicht duidelijk beperkter was dan in het oorspronkelijke amendement-Dittrich, maar nog altijd aanzienlijk ruimer dan in het regeringsvoorstel. Volgens de Minister kwam het nieuwe amendement daarmee gedeeltelijk aan zijn bezwaren tegemoet, al zou het, zij het in mindere mate, ook tot een op zichzelf onwenselijke juridisering van de bezwaarschriftenprocedure leiden. ${ }^{\mathbf{1 3}}$

Het wetsvoorstel over de kosten bestuurlijke voorprocedures voorzag ook in een aanvulling van artikel 8:75, eerste lid, van de Awb door de rechtbank uitsluitend bevoegd te maken een partij te veroordelen in de kosten die de andere partij in verband met de behandeling van het bezwaar redelijkerwijs heeft moeten maken en artikel 7:15, tweede tot en met vierde lid, van toepassing te verklaren. Daarmee werd bewerkstelligd dat de rechtbank niet langer alleen bevoegd was een partij te veroordelen in de in beroep gemaakte proceskosten, maar ook die in bezwaar. Tevens werd door deze aanvulling het toepassingsbereik van artikel 8:75a, eerste lid, van de Awb, over de intrekking van een beroep met het verzoek het bestuursorgaan in de proceskosten te veroordelen, uitgebreid tot de in bezwaar gemaakte proceskosten, aangezien daarin artikel 8:75 van de Awb van toepassing wordt verklaard. 
Vanwege de vrees van de regering voor ongewenste juridisering en aanzienlijke kosten voor bestuursorganen door de aanvaarding van het gewijzigde amendement is de Wet kosten bestuurlijke voorprocedures al in 2004, twee jaar na haar inwerkingtreding, geëvalueerd door de vakgroep bestuursrecht en bestuurskunde van de Rijksuniversiteit Groningen. Daaruit kwam naar voren dat de regeling niet tot een noemenswaardige juridisering had geleid. De bestuursorganen vinden dat het in het algemeen om dermate geringe bedragen gaat, dat ze van de toekenning geen punt maken. ${ }^{\mathbf{1 4}}$ Het vinden van een oplossing voor het geschil, zo mogelijk langs informele weg, staat volgens hen voorop.

Hoewel deze coulante houding van bestuursorganen goed is voor te stellen, merk ik op dat die in strijd is met de dwingende formulering van artikel 7:15, tweede lid, van de Awb.

\section{De voorwaarden voor vergoeding van de in bezwaar en,ter vergelijking, ookvan de in beroep gemaakte proceskosten}

In deze paragraaf komt aan de orde de in de jurisprudentie geven uitleg aan het vereiste in artikel 7:15, tweede lid, van de Awb voor vergoeding van de in bezwaar gemaakte proceskosten dat het bestreden besluit wordt herroepen wegensaan het bestuursorgaan te wijten onrechtmatigheid. Ik knip dat op in twee delen: het herroepen van het bestreden besluit en wegens aan het bestuursorgaan te wijten onrechtmatigheid. Ter vergelijking komt ook aan de orde wanneer aanspraak kan worden gemaakt op vergoeding van de in beroep gemaakte proceskosten. In de conclusie ga ik in op het verschil tussen vergoeding van de in bezwaar gemaakte proceskosten en die in beroep.

\subsection{In bezwaar gemaakte proceskosten}

\section{Wanneer is een bestreden besluit herroepen?}

Volgens vaste jurisprudentie is sprake van herroepen van een bestreden besluit als een tegen dat besluit gemaakt ontvankelijk bezwaar na heroverweging leidt tot intrekking of wijziging van het besluit. ${ }^{\mathbf{1 5}}$ Wat betreft de wijziging van het besluit is bovendien vereist dat het primaire besluit wordt gewijzigd wat betreft het daarbij beoogde of geweigerde rechtsgevolg. ${ }^{\mathbf{1 6}}$

Het herstel van aan een primair besluit klevende gebreken hoeft dus niet te betekenen dat dat besluit is herroepen. Zie bijvoorbeeld een uitspraak van de Centrale Raad van Beroep (hierna: de Raad) van 23 augustus 2006, over de weigering van een ziekte-uitkering, waarin hij overwoog dat het bestuursorgaan de daarvoor gegeven motivering had vervangen door een andere, maar dat het bestreden besluit nog altijd - onverkort - strekte tot weigering van de ziekteuitkering, zodat niet kon worden gesproken van een herroepen. ${ }^{17}$

Dat gebreken aan een besluit kunnen worden gepasseerd, blijkt ook uit artikel 6:22 van de Awb, waarin is bepaald dat een besluit waartegen bezwaar is gemaakt of beroep is ingesteld, ondanks schending van een geschreven of ongeschreven rechtsregel of algemeen rechtsbeginsel, door het orgaan dat op het bezwaar of beroep beslist in stand kan worden gelaten indien aannemelijk is dat 
de belanghebbenden daardoor niet zijn benadeeld. Van benadeling is volgens de parlementaire geschiedenis sprake als zonder deze schending een andere uitkomst van de besluitvorming mogelijk was geweest. ${ }^{\mathbf{1 8}}$

Volgens Marseille in zijn noot onder een uitspraak van de Afdeling Bestuursrechtspraak van de Raad van State (hierna: de Afdeling) van 16 december 2005 stemt het tot nadenken dat geen proceskosten worden vergoed als aan het bestreden primaire besluit ernstige gebreken kleven, zonder dat die leiden tot de herroeping van dat besluit. Hij geeft als voorbeelden besluiten die zijn gebaseerd op een volstrekt onvoldoende onderzoek naar de relevante feiten, of waaraan elke motivering ontbreekt. Dat in zo'n situatie per definitie geen aanspraak op proceskostenvergoeding bestaat, stemt volgens hem tot nadenken. Hij wijst er op dat de burger wat dat betreft beter af zou zijn geweest als het oorspronkelijke voorstel tot wijziging van artikel 7:15 van de Awb tot wet was geworden. Dat bevatte immers, zoals in paragraaf 2 aan de orde is geweest, weliswaar een strenger vergoedingscriterium (ernstige onzorgvuldigheid in strijd met het recht), maar stelde niet als voorwaarde voor vergoeding dat het primaire besluit moest zijn herroepen. ${ }^{\mathbf{1 9}}$

In een noot onder een uitspraak van de Afdeling van 5 oktober 2011 vraagt De Waard zich mijns inziens dan ook terecht af of de eis dat het besluit moet zijn herroepen wel recht doet aan de bedoeling van de wetgever, aangezien met het aanvaarde amendement van Dittrich c.s. juist was bedoeld dat de proceskosten in bezwaar "aanzienlijk eerder voor vergoeding in aanmerking komen dan in het regeringsvoorstel”. ${ }^{20}$

Een lastige bijkomstigheid van de voorwaarde dat het besluit moet zijn herroepen, waarop Marseille in zijn hiervoor aangehaalde noot nog heeft gewezen, is dat het soms lang kan duren voordat de burger definitief uitsluitsel krijgt op zijn verzoek om vergoeding van de in bezwaar gemaakte proceskosten. Dit doet zich in het bijzonder voor als het bestuursorgaan in het besluit op bezwaar het primaire besluit in stand heeft gelaten, maar de rechter dat besluit vernietigt en de zaak terugverwijst. Hij kan zich immers niet uitspreken over de in bezwaar gemaakte proceskosten zolang het lot van het bestreden primaire besluit nog niet onherroepelijk vaststaat. ${ }^{\mathbf{2 1}}$

Ik wijs er hier tot slot nog op dat als het bestuursorgaan in plaats van bij besluit op bezwaar het bestreden besluit te herroepen een nieuw primair besluit neemt, waarbij het het bestreden besluit inhoudelijk wijzigt of intrekt, het niet met het vervolgens niet-ontvankelijk verklaren van het bezwaar een proceskostenveroordeling kan ontlopen. Dat blijkt bijvoorbeeld uit een uitspraak van 31 januari 2008, waarin de Afdeling overwoog dat aangezien het bestuursorgaan vóór het besluit op bezwaar het primaire besluit had ingetrokken en vervangen door een gewijzigd besluit het er voor moest worden gehouden dat het eerste primaire besluit was herroepen. ${ }^{\mathbf{2 2}}$

\section{Wanneer valt het bestuursorgaan onrechtmatigheid te verwijten?}

Als het besluit is herroepen, komt de vraag aan de orde of het bestuursorgaan 
onrechtmatigheid ten aanzien van dat besluit kan worden verweten.

Koenraad noemt als voorbeelden uit de jurisprudentie, waarin verwijtbare onrechtmatigheid van het bestuursorgaan wordt aangenomen: onvoldoende zorgvuldig onderzoek, ten onrechte niet inwinnen van nader advies van een deskundige, handelen in strijd met geldend beleid, onjuiste waardering van feiten en omstandigheden ten tijde van het primaire besluit en het vermelden van een onjuiste wettelijke grondslag. ${ }^{23}$ Volgens de Raad is er ook bij herroeping wegens na het primaire besluit gewijzigde jurisprudentie sprake van aan het bestuursorgaan te wijten onrechtmatigheid. ${ }^{\mathbf{2 4}}$

Van Buuren \& Borman noemen als voorbeelden waarin volgens de jurisprudentie geen aan het bestuursorgaan te wijten onrechtmatigheid wordt aangenomen als de herroeping het gevolg is van verandering van omstandigheden, nieuwe beleidsinzichten of gewijzigde toepasselijke wettelijke voorschriften, of als het aan de belanghebbende zelf is te wijten dat het bestuursorgaan in de eerste instantie een fout maakte. ${ }^{\mathbf{2 5}}$

Volgens een vrij recente uitspaak van de Afdeling dient onder omstandigheden ook verwijtbaarheid aan de zijde van het bestuursorgaan te worden aangenomen, als het gebrekkige besluit is gebaseerd op onjuiste informatie van een door hem ingeschakelde derde voor wie het niet verantwoordelijk is. ${ }^{\mathbf{2 6}} \mathrm{De}$ Raad lijkt nog sneller de gebrekkigheid van een besluit aan het bestuursorgaan toe te rekenen. Zo overwoog hij in zijn uitspraak van 22 februari 2011: "nu de primaire besluiten worden herroepen, dienen deze besluiten als onrechtmatig te worden aangemerkt. Bij een inhoudelijk onjuist primair besluit is de verwijtbaarheid van het bestuursorgaan een gegeven, tenzij het aan betrokkene te wijten is dat het onrechtmatige primaire besluit is genomen".27

Ten aanzien van artikel 8:75a, eerste lid, van de Awb volgt de Raad een zelfde koers. Als de burger krachtens dit artikellid zijn beroep intrekt, omdat het bestuursorgaan geheel of gedeeltelijk aan de indiener van het beroepschrift is tegemoetgekomen, is op zijn verzoek om vergoeding van de in bezwaar gemaakte proceskosten artikel 7:15, tweede lid, van de Awb eveneens van toepassing. ${ }^{28}$ In geval van tegemoetkoming zal in de regel het bestreden besluit zijn herroepen. Of sprake was van aan het bestuursorgaan te wijten onrechtmatigheid dient nog te worden beoordeeld. De Raad heeft echter al op 7 juli 2005 uitgesproken dat bij een beslissing op een verzoek op grond van artikel 8:75a, eerste lid, van de Awb ook ten aanzien van de in bezwaar gemaakte proceskosten als regel heeft te gelden dat het enkele feit van tegemoetkomen voldoende is om de gevraagde veroordeling uit te spreken. Een andere benadering zou volgens hem afbreuk doen aan het uitgangspunt dat de rechter vanwege de intrekking van het (hoger) beroep niet meer treedt in de beoordeling van de zaak ten gronde. Artikel 7:15, tweede lid, van de Awb brengt naar de mening van de Raad evenwel met zich dat een kostenveroordeling in bezwaar achterwege dient te blijven als het bestuursorgaan aantoont dat van verwijtbare onrechtmatigheid van het in bezwaar bestreden primaire besluit geen sprake is. ${ }^{29}$ Uit recente jurisprudentie van de Raad blijkt dat hij met toepassing van artikel 8:75a van de Awb bestuursorganen veroordeelt in de proceskosten in bezwaar zonder te overwegen of hen onrechtmatigheid ten aanzien van het 
bestreden primaire besluit valt te verwijten. ${ }^{30}$

In de jurisprudentie lijkt dus soms te worden aangenomen dat het bestuursorgaan de onrechtmatigheid van een herroepen besluit kan worden verweten, zonder dat dit daadwerkelijk het geval is, of hoeft te zijn. Dat lijkt in strijd te zijn met de bedoeling van de wetgever om alleen een vergoedingsplicht voor de in bezwaar gemaakte proceskosten in het leven te roepen, als het bestuursorgaan daadwerkelijk de onrechtmatigheid van het herroepen besluit kan worden verweten. Aan de andere kant lijkt er in de jurisprudentie minder snel sprake te zijn van herroeping van het primaire besluit, dan de wetgever heeft beoogd.

\subsection{In beroep gemaakte proceskosten}

Anders dan voor de vergoeding van de in bezwaar gemaakte proceskosten gelden voor vergoeding van de in beroep gemaakte proceskosten volgens artikel 8:75, eerste lid, van de Awb geen specifieke eisen. ${ }^{\mathbf{3 1}}$ Voor vergoeding van de in beroep gemaakte proceskosten is ook niet vereist dat de burger een verzoek indient. De rechter heeft bij vergoeding van de in beroep gemaakte proceskosten beoordelingsvrijheid. Dat neemt niet weg dat er volgens Van Buuren \& Borman uit de jurisprudentie wel wat vuistregels zijn af te leiden.

Zo is bij een gegrondverklaring van het beroep en vernietiging van het besluit op bezwaar een proceskostenveroordeling van het bestuursorgaan regel.

Verwijtbaarheid van het bestuursorgaan is in beginsel niet van belang. Daarop wordt wel een uitzondering gemaakt, bijvoorbeeld als de burger (ook) verwijtbaar heeft gehandeld door het te laat verstrekken van gegevens. Hoewel bij een niet-ontvankelijkverklaring, onbevoegdverklaring, of ongegrondverklaring een proceskostenveroordeling ten gunste van de burger in beginsel achterwege blijft, is ook in deze situaties een proceskostenveroordeling mogelijk. ${ }^{22}$ In een uitspraak van 18 april 2012 overwoog Afdeling hieromtrent: "Aanleiding om een bestuursorgaan in de proceskosten te verwijzen bestaat in beginsel slechts, indien het beroep tegen een door dat bestuursorgaan genomen besluit gegrond wordt verklaard". 33

Dit sluit niet uit dat de rechter bij het passeren van gebreken in het besluit op bezwaar het bestuursorgaan kan veroordelen in de in beroep gemaakte proceskosten. Zie bijvoorbeeld een uitspraak van Raad van 24 oktober 2008. In deze zaak had de rechtbank volgens de Raad het besluit op bezwaar met toepassing van artikel 6:22 van de Awb in stand kunnen laten. Echter, aangezien de rechtbank had geoordeeld dat het bestreden besluit onvoldoende was gemotiveerd en dat gebrek eerst in beroep was hersteld, oordeelde de Raad dat de rechtbank ten onrechte de in beroep gemaakte proceskosten niet had vergoed.34

Dat niet ieder gebrek in een besluit tot vergoeding van de in beroep gemaakte proceskosten hoeft te leiden, blijkt uit een uitspraak van de Raad van 11 december 2008, waarin hij overwoog dat niet was gebleken dat de burger door het achterwege laten van de vermelding van de toepasselijke artikelen was benadeeld, zodat gelet op het bepaalde in artikel 6:22 van de Awb onvoldoende 
grond aanwezig was het bestreden besluit op dit punt niet in stand te laten en geen termen aanwezig waren om toepassing te geven aan artikel 8:75 van de Awb. 35

Als het bestuursorgaan aan het beroepschrift van de burger geheel of gedeeltelijk is tegemoetgekomen en deze daarom krachtens artikel 8:75a, eerste lid, van de Awb zijn beroep intrekt, komen zijn in beroep gemaakte proceskosten volgens de jurisprudentie voor vergoeding in aanmerking. ${ }^{\mathbf{3 6}}$ Indien de burger zijn beroep niet intrekt, terwijl aan het beroepschrift is tegemoetgekomen, is volgens jurisprudentie op basis van analoge toepassing van artikel 8:75a, eerste lid, van de Awb vergoeding van de in beroep gemaakte proceskosten mogelijk. ${ }^{37}$ Uit artikel 8:75a, eerste lid, van de Awb volgt dat bij het intrekken van een beroep, zonder dat aan het beroepsschrift is tegemoetgekomen, geen aanspraak kan worden gemaakt op vergoeding van de in beroep gemaakte proceskosten. In lijn hiermee ligt dat de burger bij een niet-ontvankelijk verklaring van zijn beroep, zonder dat aan het beroepschrift is tegemoetgekomen, in beginsel evenmin aanspraak maakt op vergoeding van zijn in beroep gemaakte proceskosten..$^{38}$

\subsection{Conclusie}

De burger komt bij de intrekking van een beroep, omdat geheel of gedeeltelijk aan de indiener van het beroepschrift is tegemoetgekomen, wettelijk gezien eerder in aanmerking voor vergoeding van zijn in beroep gemaakte proceskosten, dan die in bezwaar. Immers, anders dan voor vergoeding van de in bezwaar gemaakte proceskosten is niet vereist dat het bestuursorgaan onrechtmatigheid van het herroepen primaire besluit wordt verweten. De Raad acht echter ook als het gaat om vergoeding van de in bezwaar gemaakte proceskosten een beoordeling van de verwijtbaarheid niet opportuun als het beroep is ingetrokken wegens tegemoetkoming door het bestuursorgaan. Als het beroep wordt ingetrokken wegens tegemoetkoming door het bestuursorgaan lijkt er in de praktijk dus vaak geen groot verschil te zijn tussen de toekenning van de in bezwaar en in beroep gemaakte proceskosten.

Bij een gegrond beroep en vernietiging van het besluit op bezwaar ligt dat wat anders. De burger maakt in dat geval in de regel aanspraak op vergoeding van zijn in beroep gemaakte proceskosten. Het vernietigen van het besluit op bezwaar hoeft echter nog niet te betekenen dat het bestreden primaire besluit wordt herroepen. Zo kan de rechter bepalen dat de rechtsgevolgen van het vernietigde besluit in stand blijven. ${ }^{\mathbf{3 9}}$ Ook bestaat de kans dat het bestuurorgaan de gebreken in een nieuw besluit op bezwaar herstelt, zonder het primaire besluit te herroepen. In deze gevallen maakt de burger wel aanspraak op vergoeding van zijn in beroep gemaakte proceskosten, maar niet die in bezwaar.

Dat is ook mogelijk als de rechter het beroep ongegrond verklaart en met toepassing van artikel 6:22 van de Awb de gebreken in een besluit op bezwaar herstelt. Hij kan dan immers afhankelijk van de ernst van de geconstateerde gebreken het bestuursorgaan veroordelen in de inberoep gemaakte proceskosten, maar niet die in bezwaar, aangezien in dat geval het onderliggende bestreden primaire besluit in stand blijft. 
Het lijkt recht te doen aan de bedoeling van de weggever als bij een gegrond beroep en vernietiging van het besluit op bezwaar en bij een besluit op bezwaar, of uitspraak in beroep, waarbij met toepassing van artikel 6:22 van de Awb ernstige gebreken in het primaire besluit onderscheidenlijk het besluit op bezwaar worden gepasseerd, ook de mogelijkheid zou bestaan de in bezwaar gemaakte proceskosten te vergoeden. Van ernstige gebreken lijkt mij sprake als bij de burger de indruk kon ontstaan dat zonder die gebreken een ander inhoudelijk besluit mogelijk zou zijn geweest.

\section{Procesbelang als het de burger nog uitsluitend belang heeft bij vergoeding van zijnproceskosten}

In deze paragraaf komt eerst aan de orde het procesbelang als de burger nog uitsluitend procedeert over zijn in bezwaar, en ter vergelijking, zijn in (hoger) beroep gemaakte proceskosten. Vervolgens ga ik daarop nog nader in door het plaatsen van een aantal kanttekeningen.

\subsection{Procesbelang als de burger nog uitsluitend procedeert over zijn in bezwaar, en ter vergelijking, zijn in (hoger) beroep gemaakte proceskosten}

Als het bestuursorgaan het bestreden besluit herroept wegens aan hem te wijten onrechtmatigheid dient het een tijdig ingediend verzoek om vergoeding van de in bezwaar gemaakte proceskosten te honoreren. Het kan echter ook voorkomen dat het bestuursorgaan het primaire besluit weliswaar herroept, maar geen proceskosten vergoedt, omdat het meent dat hem geen onrechtmatigheid ten aanzien van het herroepen besluit valt te verwijten.

Een bezwaar of (hoger) beroep dat wegens de herroeping van het bestreden besluit nog uitsluitend gaat over een niet ingewilligd verzoek om vergoeding van de in bezwaar gemaakte proceskosten is ontvankelijk, zoals bijvoorbeeld blijkt uit een uitspraak van de Afdeling van 23 juni $2004 .^{40}$ In deze zaak had het bestuursorgaan het besluit, waarbij het de burger had gelast het hotelgedeelte van zijn bedrijf gesloten te houden, ingetrokken en het bezwaar wegens het ontbreken van procesbelang niet-ontvankelijk verklaard. De Afdeling oordeelde dat nu de burger in zijn bezwaarschrift had verzocht om vergoeding van de proceskosten niet kon worden staande gehouden dat hij geen belang had bij het verkrijgen van een oordeel op zijn bezwaar, zodat het bestuursorgaan het bezwaar ten onrecht niet-ontvankelijk had verklaard en voorts in strijd met artikel 7:15, van de Awb had nagelaten te beoordelen of het verzoek om vergoeding van de proceskosten voor inwilliging in aanmerking kwam. De rechtbank had het beroep in zoverre dan ook ten onrechte ongegrond verklaard volgens de Afdeling. ${ }^{41}$

Ook als de burger zijn belang bij de herroeping van het bestreden besluit ergens in de procedure is kwijtgeraakt, maar nog wel zijn tijdig ingediende verzoek om vergoeding van zijn in bezwaar gemaakte proceskosten gehonoreerd wil zien, heeft hij belang bij een inhoudelijke beoordeling van zijn bezwaar, dan wel (hoger) beroep. In deze situatie is de inhoudelijke beoordeling meeromvattend dan die hiervoor, waarin het bestreden besluit reeds is herroepen en waar gelet 
op artikel 7:15, tweede lid, van de Awb nog dient te worden beoordeeld of dat is gebeurd wegens aan het bestuursorgaan te wijten onrechtmatigheid. Hier dient immers gelet op die bepaling ook, en in de eerste plaats, te worden of het primaire besluit in rechte stand kan houden, of dat het dient te worden herroepen.

Een mooi voorbeeld van een zaak over procesbelang, waarin de burger zijn belang bij herroeping van het bestreden besluit al in de bezwaarfase was kwijtgeraakt, vormt een uitspraak van de Afdeling van 15 december $2010 .{ }^{42}$ In deze zaak had het bestuursorgaan het bezwaar niet-ontvankelijk verklaard wegens het ontbreken van procesbelang, omdat de in het primaire besluit opgelegde verblijfsontzegging inmiddels was uitgewerkt. Het had daarbij echter niet onderkend dat tevens om vergoeding van de in bezwaar gemaakte proceskosten was verzocht. ${ }^{43}$ De rechtbank had de beslissing op bezwaar om deze reden vernietigd en de zaak terugverwezen. De Afdeling verklaarde het daartegen door het bestuursorgaan ingestelde hoger beroep ongegrond en bevestigde de uitspraak van de rechtbank. Inmiddels had het bestuursorgaan een nieuw besluit op het bezwaar genomen en het ongegrond verklaard. Dit besluit betrok de Afdeling op grond van artikel 6:24 van de Awb, in samenhang bezien met de artikelen 6:18, eerste lid, en 6:19, eerste lid, van de Awb, mede in het geding. Vervolgens verklaarde de Afdeling het beroep tegen dit nieuwe besluit op bezwaar gegrond en vernietigde zij het. ${ }^{44}$ De Afdeling beoordeelde vervolgens of de rechtsgevolgen van het vernietigde besluit in stand konden blijven. Gelukkig bleek dat het geval te zijn, want anders had het bestuursorgaan zich weer opnieuw over de (on) rechtmatigheid van verblijfsontzegging moeten buigen, die al ruim twee jaar daarvoor was uitgewerkt, uitsluitend vanwege het gedane verzoek om vergoeding van de in bezwaar gemaakte proceskosten. ${ }^{45}$

Een voorbeeld, waarin de burger zijn belang bij de herroeping van het bestreden besluit in de beroepfase is kwijtgeraakt, vormt een uitspraak van de Raad van 13 oktober 2009 over een afwijzing om met behoud van een bijstandsuitkering een opleiding te mogen volgen. Aangezien hangende beroep de bijstandsuitkering inmiddels was beëindigd en de burger de gewenste opleiding was gaan volgen met een uitkering op grond van de Wet studiefinanciering had de rechtbank het beroep niet-ontvankelijk verklaard. De Raad oordeelde dat dit onjuist was. Hij overwoog als volgt:" Met appellante en anders dan de rechtbank is de Raad van oordeel dat appellante belang had bij een inhoudelijke beoordeling van haar beroep door de rechtbank. Immers, voor het antwoord op de vraag of het College terecht het verzoek om vergoeding van de kosten van rechtsbijstand in de bezwaarfase heeft afgewezen, diende de rechtbank, gelet op artikel 7:15, tweede lid, eerste volzin, van de Algemene wet bestuursrecht te onderzoeken of de afwijzing van het verzoek van appellante om met behoud van bijstand de opleiding tot leidster kinderopvang te volgen, in rechte stand kon houden. De rechtbank heeft het beroep dan ook ten onrechte niet-ontvankelijk verklaard”.46

Als de burger nog uitsluitend zijn in (hoger) beroep gemaakte proceskosten vergoed wil zien, omdat het bestreden besluit is herroepen, of omdat de burger zijn belang daarbij heeft verloren, is zijn (hoger) niet ontvankelijk. De vraag of een proceskostenveroordeling moet worden uitgesproken vormt onvoldoende procesbelang om tot een inhoudelijke beoordeling van het (hoger) beroep over te 
gaan. ${ }^{47}$ De rechter doet in dat geval zonder inhoudelijke beoordeling van het geschil uitspraak over de vergoeding van de in (hoger) beroep gemaakte proceskosten en heeft daarbij beoordelingsvrijheid, zoals in paragraaf 3.2 aan de orde is geweest. Tegen de (gedeeltelijke) afwijzing van de in beroep gemaakte proceskosten door de lagere rechter staat hoger beroep open. ${ }^{\mathbf{4}}$

\subsection{Kanttekeningen bij het procesbelang}

Het procesbelang van de burger bij het procederen over nog uitsluitend zijn proceskosten in (tevens) bezwaar geeft aanleiding tot misverstanden, nu hij geen procesbelang heeft bij het uitsluitend procederen over zijn proceskosten in (hoger) beroep. Dat blijkt mooi uit een uitspraak van de Raad van 27 maart 2009. In deze zaak had de rechtbank overwogen dat de burger niet in zijn beroep kon worden ontvangen, omdat het enkel was gericht op het verkrijgen van een proceskostenvergoeding. De rechtbank verklaarde zich daarbij te baseren op vaste jurisprudentie van de Raad (onder meer LJN BBo717), dat een belang bij vernietiging van een besluit niet enkel kan zijn gelegen in het verkrijgen van een proceskostenvergoeding. ${ }^{49}$ De Raad overwoog dat de door de rechtbank genoemde jurisprudentie niet zag op de onderhavige situatie. In de door de rechtbank aangehaalde zaak ging het om de proceskosten in eerste aanleg, dan wel hoger beroep, terwijl het de burger in dit geval (tevens) ging om de proceskosten in de bezwaarfase. Naar zijn oordeel had de burger wel degelijk belang bij de beoordeling van het bestreden besluit, aangezien daarbij de vergoeding van de in bezwaar gemaakte proceskosten was geweigerd.50

Het blijkt regelmatig voor te komen dat bestuursorganen en rechters ten onrechte menen dat een bezwaar, of (hoger) beroep wegens het ontbreken van procesbelang niet ontvankelijk is als het bestreden primaire besluit hangende de bezwaar- of (hoger)beroepsprocedure is herroepen en alleen het tijdige verzoek om vergoeding van de in bezwaar gemaakte proceskosten niet is gehonoreerd. $\mathbf{5 1}^{\mathbf{1}}$ Dat zelfde geldt als de burger geen belang meer heeft bij de herroeping van het bestreden besluit, maar alleen nog bij vergoeding van zijn in bezwaar gemaakte proceskosten..$^{2}$

Het lijkt mij dat daarbij meespeelt dat het niet voor de hand ligt dat de burger belang heeft bij een inhoudelijke beoordeling van zijn bezwaar, dan wel (hoger) beroep als het hem alleen nog gaat om vergoeding van zijn (tevens) in bezwaar gemaakte proceskosten. Dat geldt zeker in de situatie dat hij zijn belang bij herroeping van het bestreden primaire besluit heeft verloren. Dat dan desondanks moet worden beoordeeld of het primaire besluit in rechte stand kan houden, brengt immers mee dat het besluit geen rechtskracht kan krijgen. Als (uiteindelijk) zou komen vast te staan dat het primaire besluit dient te worden herroepen en dat besluit dus onrechtmatig was, zou de burger daarin bovendien aanleiding kunnen zien een procedure te starten om zijn door het onrechtmatige besluit geleden schade vergoed te krijgen. Voorts doet het vreemd aan als een primair besluit wordt herroepen, terwijl daarbij geen belang meer bestaat, alleen wegens een verzoek om vergoeding van de in bezwaar gemaakte proceskosten. Dat geldt zeker als de procederende burger niet de geadresseerde is van het primaire besluit. 
De wetgever lijkt bij de aanname van het amendement van Dittrich c.s. geen aandacht te hebben gehad voor de situatie dat de burger ergens in de procedure zijn belang bij de herroeping van het bestreden besluit verliest en alleen nog belang houdt bij vergoeding van zijn in bezwaar gemaakte proceskosten. Gelet op de duur van juridische procedures zal die situatie zich echter regelmatig voordoen.

\section{Aansluiten bij de proceskosten in beroep?}

\subsection{Wat vooraf ging}

In paragraaf 2 is aan de orde geweest dat de regering in het karakter van de bezwaarschriftenprocedure, die mede is gericht op herstel van gemaakte fouten, reden zag om voor de in bezwaar gemaakte proceskosten een regeling te treffen afwijkend van de regeling voor de in beroep gemaakte proceskosten. Bovendien wilde zij de bestuurslasten binnen de perken houden. Zij vreesde als gevolg van de aanname van het amendement van Dittrich c.s. voor juridisering van de bezwaarschriftenprocedure en stijging van de bestuurslasten.

Uit de in 2004 verrichte evaluatie van de Wet kosten bestuurlijke voorprocedures bleek echter niet van noemenswaardige juridisering, aangezien bestuursorganen vanwege de geringe bedragen van de toekenning van proceskosten in bezwaar geen punt maakten. Zo'n coulante houding is echter in strijd met de dwingende formulering van artikel 7:15, tweede lid, van de Awb.

In paragraaf 3 bleek dat de in jurisprudentie gegeven uitleg aan herroepen dat het rechtsgevolg van het bestreden besluit wijzigt, niet helemaal lijkt overeen te komen met de bedoeling van de wetgever. Hierdoor kan het voor de burger behoorlijk lastig zijn om zijn in bezwaar gemaakte proceskosten vergoed te krijgen. Tevens bleek dat de burger door het vereiste van herroepen mogelijk lang moet wachten op uitsluitsel over het recht op die vergoeding. Aan de andere kant bleek dat als het primaire besluit eenmaal is herroepen zeker door de Raad, vrij gemakkelijk wordt aangenomen dat het bestuursorgaan de onrechtmatigheid van dat besluit kan worden verweten. Tevens kwam aan de orde de beoordelingsvrijheid die de rechter heeft bij vergoeding van de in beroep gemaakte proceskosten en de invulling die daaraan in de jurisprudentie is gegeven.

In de paragraaf 4 kwam naar voren dat een bezwaar, of (hoger) beroep dat nog uitsluitend gaat over een niet ingewilligd tijdig verzoek om vergoeding van de (tevens)in bezwaar gemaakte proceskosten, omdat het bestreden besluit is herroepen, of omdat de burger zijn belang daarbij heeft verloren inhoudelijk dient te worden beoordeeld. Voorts bleek dat bestuursorganen en rechters vaak ten onrechte menen dat zo'n bezwaar of (hoger) beroep niet-ontvankelijk is wegens het ontbreken van procesbelang. Daarbij bleek dat een rol te spelen dat een (hoger) beroep over nog uitsluitend de in (hoger) beroep gemaakte proceskosten wél niet-ontvankelijk is en waarschijnlijk ook dat procesbelang wegens een verzoek om vergoeding van de (tevens) in bezwaar gemaakte proceskosten niet voor de hand ligt. Dat geldt zeker in de situatie dat de burger zijn belang bij de herroeping van het bestreden besluit heeft verloren, gelet op 
mogelijke, onwenselijke gevolgen als toch geoordeeld zou worden dat dat besluit in rechte geen stand kan houden.

De hier geschetste nadelen bij de vergoeding van de in bezwaar gemaakte proceskosten doen zich niet voor bij de vergoeding van de in beroep gemaakte proceskosten. In de wetenschap dat de wetgever bewust voor de in bezwaar gemaakte proceskosten een terughoudendere vergoedingsplicht in het leven heeft willen roepen, laat ik tot slot mijn gedachten gaan over de gevolgen als deze proceskosten toch op dezelfde manier zouden worden vergoed als die in beroep. Daarna sluit ik af met een conclusie.

\subsection{De gevolgen van aansluiting bij de proceskosten in beroep}

Aansluiting bij artikel 8:75, eerste lid, van de Awb betekent in plaats van het vereiste dat het bestreden besluit wordt herroepen wegens aan het bestuursorgaan te wijten onrechtmatigheid beoordelingsvrijheid bij de vergoeding van de in bezwaar gemaakte proceskosten. Het lijkt mij voor de hand liggen dat bij de invulling daarvan in dat geval zo veel mogelijk wordt aangesloten bij de wijze waarop rechters de in beroep gemaakte proceskosten vergoeden, omdat verschillen daarin opnieuw tot misverstanden aanleiding kunnen geven.

Zoals uit paragraaf 3.2 volgt, brengt dat in grote lijnen mee dat de rechter aanleiding kan zien het bestuursorgaan in de in bezwaar gemaakte proceskosten te veroordelen bij een gegrond beroep en het vernietigen van het besluit op bezwaar en bij een ongegrond beroep met het passeren van ernstige gebreken in het besluit op bezwaar. In deze situaties is dan in beginsel niet langer het herroepen van het bestreden besluit vereist. Ook in de intrekking van een beroep en een niet-ontvankelijkverklaring daarvan wegens tegemoetkoming door het bestuursorgaan hangende de beroepsprocedure kan de rechter dan in beginsel aanleiding zien het bestuursorgaan te veroordelen in de in bezwaar gemaakte proceskosten. Daarbij speelt dan in de regel geen rol meer of het bestuursorgaan onrechtmatigheid van het herroepen primaire besluit kan worden verweten. Daarbij merk ik nog een keer op dat ook nu al, zeker door de Raad, de gebrekkigheid van een herroepen besluit vrij gemakkelijk aan het bestuursorgaan wordt toegerekend. In andere dan de hier genoemde situaties hoeft de rechter in beginsel geen aanleiding te zien om de in bezwaar gemaakte proceskosten te vergoeden.

Aansluiting bij artikel 8:75, van de Awb betekent niet alleen beoordelingsvrijheid voor de rechter, maar ook, en in de eerste plaats, beoordelingsvrijheid voor het bestuursorgaan ten aanzien van een verzoek om vergoeding van de in bezwaar gemaakte proceskosten. Aansluiting bij de wijze waarop de in beroep gemaakte proceskosten worden vergoed, betekent dat bij een gegrond bezwaar en het herroepen van het primaire besluit, alsmede bij een ongegrond bezwaar met het passeren van ernstige gebreken in het primaire besluit voor het bestuursorgaan aanleiding zou kunnen bestaan de in bezwaar gemaakte proceskosten te vergoeden. Dat geldt ook bij intrekking van een bezwaar wegens tegemoetkoming door het bestuursorgaan hangende de bezwaarprocedure, waarvoor een regeling analoog aan artikel 8:75a, eerste lid, 
van de Awb in het leven kan worden geroepen, en bij een nietontvankelijkverklaring van het bezwaar wegens tegemoetkoming door het bestuursorgaan. In andere dan de hier genoemde situaties hoeft het bestuursorgaan in beginsel geen aanleiding te zien om de in bezwaar gemaakte proceskosten te vergoeden.

Bestuursorganen zouden op dit punt beleid kunnen ontwikkelen, waarin zij nuanceringen kunnen aanbrengen, bijvoorbeeld door bij verwijtbaar handelen van de burger het recht op vergoeding uit te sluiten. Ook omdat tegen de beslissing van het bestuursorgaan op het verzoek om vergoeding van de in bezwaar gemaakte proceskosten beroep openstaat, zou het ontwikkelen van zulk beleid zijn aan te bevelen.

$\mathrm{Nu}$ bij de aansluiting bij artikel 8:75, eerste lid, van de Awb een inhoudelijke beoordeling van het bezwaar of (hoger) beroep achterwege blijft, ligt voor de hand

dat niet bij besluit op bezwaar over de vergoeding van de in bezwaar gemaakte proceskosten wordt beslist. Dat kan, zoals bij de proceskosten in beroep, ook apart als artikel 7:15, derde lid, van de Awb in dat opzicht wordt gewijzigd. Met het handhaven van het bepaalde artikel 7:15, tweede lid, dat de kosten die de belanghebbende in verband met de behandeling van het bezwaar redelijkerwijs heeft moeten maken door het bestuursorgaan uitsluitend kunnen worden vergoed op verzoek van de belanghebbende en het bepaalde in derde lid dat dit verzoek wordt gedaan, voordat het bestuursorgaan op het bezwaar heeft beslist, blijft er in zoverre een zekere begrenzing aan het vergoeden van deze kosten.

Procedures over uitsluitend nog de proceskosten in (tevens) bezwaar worden hierdoor eenvoudiger, en naar verwachting dus ook goedkoper. Immers:

I. Als het bestuursorgaan het bestreden besluit hangende de bezwaar- of (hoger) beroepsprocedure herroept en het oorspronkelijke materiële geschil daarmee is opgelost, is het bezwaar of (hoger) beroep nietontvankelijk wegens het ontbreken van procesbelang;

II. Als de burger zijn belang bij de herroeping van het bestreden besluit hangende de bezwaar- of (hoger) beroepsprocedure is kwijtgeraakt, is zijn bezwaar of (hoger) beroep eveneens niet-ontvankelijk wegens het ontbreken van procesbelang;

III. De burger kan als het bestuursorgaan aan hem is tegemoetgekomen zijn bezwaarschrift intrekken, hetgeen nu alleen kan met een (hoger) beroepschrift.

Als daarvoor een tijdig verzoek is ingediend, bestaat dan in beginsel in de situaties I en III aanspraak op vergoeding van de in bezwaar gemaakte proceskosten en in situatie II niet. In situatie II lijkt de vergoedingsplicht dan minder ruim dan bij toepassing van het huidige artikel 7:15, tweede lid, van de Awb, in welk geval immers aanspraak bestaat op vergoeding van de in bezwaar gemaakte proceskosten als wordt voldaan aan het vereiste dat het bestreden 
besluit wordt herroepen wegens aan het bestuursorgaan te wijten onrechtmatigheid. 53

Te overwegen valt tegen deze besluiten direct beroep open te stellen.

Met een zelfde regeling voor vergoeding van de in bezwaar en in beroep gemaakte proceskosten wordt deze materie bovendien begrijpelijker, waardoor foute beslissingen door bestuursorganen en rechters kunnen worden verminderd en minder hoeft te worden geprocedeerd.

\subsection{Conclusie}

$\mathrm{Nu}$ gelet op het voorgaande per saldo de financiële lasten voor de overheid wel eens zouden kunnen meevallen als de proceskosten in bezwaar op dezelfde wijze worden vergoed als die in beroep en daarmee bovendien de in deze bijdrage geconstateerde knelpunten worden opgelost, lijkt mij dat een serieuze overweging waard.

\section{Noten}

1 De bezwaarschriftenprocedure heeft ook de functie van rechtsbescherming.

2 Daarvan zijn de kosten van door een derde beroepsmatig verleende rechtsbijstand de belangrijkste. Andere kosten zijn bijvoorbeeld de kosten van een deskundige, getuige of tolk en reis- en verblijfkosten van een partij of belanghebbende. Zie artikel 7:15, vierde lid, van de Awb in verbinding met artikel 1 van het Besluit proceskosten bestuursrecht.

3 Vanwege de leesbaarheid zal ik de belanghebbende, die de tegenpartij is van het bestuursorgaan aanduiden als de burger.

4 Hieronder vallen bezwaar en administratief beroep. In deze bijdrage richt ik mij op bezwaar, aangezien administratief beroep tegenwoordig nauwelijks meer voorkomt. Artikel 7:28, tweede lid, van de Awb over administratief beroep is gelijkluidend aan artikel 7:15, tweede lid.

5 Stb. 2002, 55 .

6 Artikel 8:75 van de Awb is van overeenkomstige toepassing op hoger beroep. Sinds 1 januari 2013 is dat geregeld in artikel 8:108, eerste lid, van de Awb.

Daarvoor was dat geregeld in 39 lid 1 Wet RvS; art. 21 lid 1 Beroepswet; 22 lid 1 Wbbo 29 AWR.

7 Zie nader rapport en memorie van toelichting, Parl. Gesch. Abw II, p. 484 en 487.

8 Zie bijvoorbeeld HR 26 september 1986, $A B$ 1987, 70 en HR 20 februari 1998, JB 1998, 72.

9 Kamerstukken II 1999/o0, 27 024, nrs. 1-2. 
10 Kamerstukken II 1999/o0, 27 024, nr. 3.

11 Kamerstukken II 1999/o0, 27024 nr.7.

12 Amendement door Dittrich, Stanti, Van Wijmen en Van der Staaij, Kamerstukken II 1999/o0, 27 024, nr. 14.

13 Kamerstukken II 2000/01, 27024, nr. 15.

14 Zie het eindrapport Evaluatie Wet kosten bestuurlijke voorprocedures van de Rijksuniversiteit Groningen uit december 2004, p. 62 en 67 te raadplegen op www.wodc.nl. Zie ook H.B Winter \& A.T. Marseille, 'De Wet kosten bestuurlijke voorprocedures geëvalueerd', Gst. 2005, 118.

15 Zie bijvoorbeeld ABRvS 27 april 2005, 200407125/1, ABRvS 16 december 2005, $A B$ 2006, 176, m.nt. Marseille en CRvB van 5 januari 2007, LJN AZ 6642.

16 Zie bijvoorbeeld van de CRvB van 23 augustus 2006, LJN AY8044 en ABRvS 11 juni 2010, LJN BO9728.

17 Zie CRvB 23 augustus 2006, $A B$ 2007, 122. De rechtbank had in deze zaak daarentegen overwogen dat wél sprake was van herroeping, omdat het bestreden besluit was gebaseerd op een onjuiste eerste ziektedag, zodat het besluit inhoudelijk onjuist was. Daarnaast speelde voor de rechtbank een rol dat het bestuursorgaan bij besluit op bezwaar een andere grondslag onder de afwijzing van de gevraagde ziekte-uitkering had gelegd. Zie ook ABRvS 5 oktober 2011, $A B$ 2011, 322, waarin met een beroep op de Wob was gevraagd om de verstrekking van een certificaat van bekwaamheid. In het primaire besluit werd het certificaat niet genoemd. In het besluit op bezwaar werd over dat certificaat vermeld dat het niet kon worden verstrekt, omdat het niet bestond. Volgens de Afdeling had het bezwaar geleid tot verbetering van de motivering, maar niet tot herroeping van het primaire besluit, nu het besluit het certificaat van bekwaamheid niet te verstrekken bij besluit op bezwaar was gehandhaafd. Zie ook CRvB 10 februari 2012, LJN BV6637. Per 1 januari 2013 is artikel 6:22 van de Awb gewijzigd, waardoor het bij schending van een ongeschreven of geschreden rechtsregel of algemeen rechtsbeginsel kan worden toegepast. Daarvoor was dat alleen mogelijk bij schending van een vormvoorschrift.

18 Zie memorie van toelichting, Parl. Gesch. Awb I, p. 313-314.

19 ABRvS 16 december 2005, $A B$ 2006, 176, m.nt. Marseille.

20 ABRvS 5 oktober 2011, $A B$ 2011/322, m.nt. De Waard.

21 Dat de rechter het geschil tegenwoordig zoveel mogelijk definitief beslecht, hetgeen per 1 januari 2013 ook in de Awb, in artikel 8:41a, is opgenomen, heeft in ieder geval een gunstige invloed op de duur van procedures.

22 Zie ABRvS 31 januari 2008, JB 2008,60. Zie ook CRvB 13 juni 2005, USZ 2005, 287, m.nt. Schuurmans. In dit verband verwijs ik voorts naar de uitspraak 
van de Afdeling van 16 juli 2008, $J B$ 2008, 196. Hierin heeft zij geoordeeld dat een inhoudelijk besluit na herroeping van een primair besluit, waarbij de aanvraag buiten behandeling was gesteld, deel uitmaakt van de beslissing op bezwaar. Ook in dat geval biedt het nemen van een nieuw primair besluit geen ontsnapping aan een proceskostenveroordeling.

23 L.M. Koenraad, 'Module Algemeen Bestuursrecht, Commentaar op Artikel 7:15 Awb,' te raadplegen via Legal intelligence, Tekst en Commentaar Awb bij artikel 7:15 van de Awb.

\section{Zie CRvB 3 maart 2009, LJN BH6o87.}

25 P.J.J. van Buuren \& T.C. Borman, Tekst en Commentaar Algemene wet bestuursrecht, Deventer: Kluwer 2011, commentaar bij artikel 7:15 Awb.

26 ABRvS 24 februari 2012, $J B$ 2012, 88 m.nt.Keinemans. In deze zaak was het bestuursorgaan afgegaan op door de Belastingdienst verstrekte informatie.

27 CRvB 22 februari 2011, LJN PB5571. Zie ook CRvB 15 september 2010, LJN $\mathrm{BN} 7153$.

28 In artikel 8:75a, eerste lid, van de Awb is artikel 8:75 van de Awb van toepassing verklaard, dat weer verwijst naar artikel 7:15, tweede lid, van de Awb. De term tegemoetkomen is tijdens de parlementaire geschiedenis niet nader ingevuld. Volgens Van Buuren \& Borman 2011, commentaar bij artikel 8:75a Awb, moet van geval tot geval worden bezien of er materieel sprake is van tegemoetkomen. Onder verwijzing naar jurisprudentie stellen zij dat de term restrictief wordt uitgelegd, aangezien er een relatie wordt verlangd tussen de gronden van het beroep en het besluit, waarmee het bestuursorgaan alsnog de wensen van de indiener van het beroepschrift honoreert. Zie ook uitspraak van Afdeling van 5 oktober 2000, $L J N$ ABooo9, waarin zij overweegt dat is tegemoetgekomen als "het bestuursorgaan het door de indiener van het beroepschrift gewenste besluit geheel of gedeeltelijk neemt, tenzij dit besluit kennelijk is genomen op andere gronden dan de indiener van het beroepschrift heeft aangevoerd".

29 CRvB 7 juli 2005, LJN AT9764. Volgens J.A.C. de Poorter, 'Kroniek Bestuursprocesrecht', NTB 2006, 14 overtuigt dit standpunt van de Raad niet. Aangezien artikel 7:15, tweede lid, van de Awb - anders dan artikel 8:75 Awb voor de kosten van het beroep bij de rechter - de proceskostenveroordeling uitdrukkelijk aan de rechtmatigheid van het besluit koppelt, levert de enkele intrekking van het primaire besluit volgens hem nog geen titel op voor een veroordeling van het bestuur in de kosten van bezwaar. Het College van Beroep voor het Bedrijfsleven (hierna: het College) lijkt blijkens zijn uitspraak van 21 juni 2005, LJN AT8200 dezelfde mening te zijn toegedaan. Het stelt hier dat vanwege de intrekking van het beroep, omdat het bestuursorgaan is tegemoetgekomen, geen recht op vergoeding van de in bezwaar gemaakte proceskosten bestaat. Als de burger daarover een uitspraak wenste te verkrijgen, had hij zijn beroep volgens het College niet mogen intrekken, omdat dan met het nieuwe besluit op bezwaar niet geheel aan zijn beroep was tegemoetgekomen. 
30 Zie bijvoorbeeld CRvB 20 april 2012, $L J N$ BW3639, CRvB 6 juni 2012, $L J N$ BW8010 en CRvB 18 juli 2012, LJN BX2130.

31 Artikel 8:75 van de Awb is van overeenkomstige toepassing op hoger beroep. Dat daarbij de rechtbankuitspraak ter beoordeling staat en zowel de burger als het bestuursorgaan daartegen in hoger beroep kunnen komen, brengt mee dat de vergoeding van de proceskosten in hoger beroep zich minder makkelijk leent voor een vergelijking met vergoeding van de proceskosten in bezwaar. Ik beperk me daarom hier tot de vergoeding van de proceskosten in beroep.

32 Zie Van Buuren en Borman 2011, commentaar bij artikel 8:75 Awb.

33 ABRvS 18 april 2012, $L J N$ BW3082.

34 CRvB 24 oktober 2008, LJN BG1763.

35 CRvB 11 december 2008, LJN BG8431. Nu de mogelijkheid van het passeren van gebreken met de wijziging van artikel 6:22 van de Awb per 1 januari 2013 is verruimd doordat niet meer alleen schending van vormvoorschriften kunnen worden gepasseerd, maar schending van een geschreven of ongeschreven rechtsregel of algemeen rechtsbeginsel, bestaat de kans dat de rechter vaker een beroep ongegrond zal verklaren en wegens gepasseerde gebreken een proceskostenveroordeling zal uitspreken. Indien echter aannemelijk is dat belanghebbenden daardoor worden benadeeld, is het passeren van gebreken volgens dit artikel niet mogelijk en zal de rechter het beroep dus gegrond moeten verklaren.

36 Zie bijvoorbeeld CRvB 20 april 2012, LJN BW3639.

37 Zie bijvoorbeeld ABRvS 23 februari 2011, LJN BP5442.

38 Zie bijvoorbeeld ABRvS 4 april 2012, LJN BWo783.

39 Zie artikel 8:72, derde lid, aanhef en onder a, van de Awb.

40 Het bestuursorgaan kan bij besluit op bezwaar een primair besluit herroepen, maar ook bij een nieuw primair besluit, waardoor de bezwaarprocedure nog uitsluitend over de vergoeding van de proceskosten kan gaan. Hierbij verwijs ik nog even naar paragraaf 3.1, waarin is vermeld dat als het bestuursorgaan in plaats van een besluit op bezwaar een nieuw primair besluit neemt, waarbij het bestreden primaire besluit inhoudelijk wordt gewijzigd of ingetrokken, wordt aangenomen dat het bestreden besluit is herroepen.

41 ABRvS 23 juni 2004, LJN AP3399.

42 ABRvS 15 december 2010, $A B$ 2011, 237, m.nt. Brouwer en Schilder.

43 Hoewel in dit verband niet aan de orde, wijs ik er volledigheidshalve op dat uit jurisprudentie van de Afdeling, bijvoorbeeld de uitspraak van 19 mei 2010, 
$L J N$ BN2806, blijkt dat procesbelang bij verblijfsontzegging en huisverbod ook gelegen kan zijn in de omstandigheid dat deze verboden een publiekrechtelijke afwijzing inhouden van het bedrag van de betrokkene.

44 De reden daarvoor was dat de burger in strijd met artikel 7:9 van de Awb voorafgaand aan de beslissing op bezwaar niet in de gelegenheid was gesteld te reageren op een politierapport.

45 In deze zaak was het voor de rechtbank niet mogelijk het geschil definitief te beslechten, omdat het bestuursorgaan het bezwaar vanwege de nietontvankelijkverklaring daarvan nog niet inhoudelijk had beoordeeld.

46 CRvB 13 oktober 2009, LJN BKo681

47 Zie bijvoorbeeld CRvB 31 juli 2007, LJN BBo717, ABRvS 4 juni 2009, LJN BI7551, CBB 24 januari 2012, LJN BV2276, HR 23 maart 2012, LJN BVo655.

48 Zie bijvoorbeeld CRvB 1 oktober 2009, LJN BJ8854.

49 Het betreft de uitspraak van de CRvB van 31 juli 2007, LJN BBo717.

50 CRvB 27 maart 2009, JB 2009, 147 m.nt. Keinemans.

51 Zie bijvoorbeeld ABRvS 23 juni 2004, LJN AP3399, ABRvS 23 juni 2004, $L J N$ BD8321, CRvB 17 mei 2011, $L J N$ BQ 6322, ABRvS 11 juli 2012, $L J N$ BX1034.

52 Zie bijvoorbeeld ABRvS 18 februari 2009, LJN BH3240, CRvB 25 februari 2009, LJN BH6363, CRvB 15 december 2009, LJN BK6670, CRvB 9 november 2010, $L J N$ BO3422, CRvB 5 januari 2011, $L J N$ BO9957, CRvB 23 februari 2011, $L J N$ BP5682, ABRvS 28 maart 2012, LJN BW0142, ABRvS 6 juni 2012, LJN BW7599, CRvB 17 juli 2012, LJN BX2123, CRvB 13 november 2012, LJN BY4176.

53 Deze minder ruime vergoedingsmogelijkheid is ook logisch, nu bij de intrekking van een beroep wegens het ontvallen van procesbelang in beginsel ook een aanspraak bestaat op proceskostenvergoeding. Er is immers geen sprake van tegemoetkoming aan de indiener van het beroepschrift.

(C) Boom Juridische uitgevers 